\title{
Online Education Program for English Learners in High Schools
}

\author{
Ms. Qing Chen \\ Director of English Department, Experimental High School Affiliated to Beijing Normal University, China \\ *Corresponding Author: Ms. Qing Chen, Director of English Department, Experimental High School \\ Affiliated to Beijing Normal University, China
}

\begin{abstract}
:
Aim:

This study aims to build a model for online education program for English learners using logistic regression model.

\section{Methods:}

A public database was used in this study. All the participants who were eligible were randomly assigned into 2 groups: training sample and testing sample. Logistic regression was built using training sample. We used these two models to predict the career satisfaction of software developers in the testing sample. Sensitivity, specificity, receiver operating characteristic (ROC) were calculated.
\end{abstract}

\section{Results:}

A total of 918 schools offered online program for the English learners, representing about $79.1 \%$ of the total of 1161 schools.

Schools in Southeast were $208 \%$ more likely to provide online program for English learners than schools in Northeast. Central and West regions had a slightly higher likelihood to offer online program than Northeast, however, the differences were not significant.

Schools which did not offer bilingual instruction were $52 \%$ less likely to offer online English education. Schools which did not offer English as a Second Language (ESL) instruction were $45 \%$ less likely to offer online education. Schools which did not offer English as a Second Language (ESL) push-in or pull-out instruction were 33\% less likely to have online program for English learners. Schools which did not provide instructional support by a paraprofessional who speaks the student's native language were 35\% less likely to have online program.

The area under curve was 0.6479. The optional cutoff time is 0.4262. The mis-classification error was 0.2083. the sensitivity rate is about $100 \%$ and the specificity is $0.8 \%$.

Conclusions:This study identified the potential predictors for online education for English learners, for example: regions, availability of other support for English as a Second Language.

Keywords: Online Education, English learners, English as a Second Language, logistic regression, ROC

\section{INTRODUCTION}

Modern technology connects us and allows communities to share resources in unprecedented ways. Virtual education leverages these connections to provide everyone, regardless of geographic location, access to experts and high quality learning experiences. As technology has improved, virtual education has evolved to become a tool that helps close gaps in high schools and colleges. Quality online learning programs provide rigorous curriculum, meaningful teaching resources, and access to specialized programs, such as industry training for students, schools and teachers. ${ }^{i}$

The Babson Survey Research Groups latest report Grade Increase: Tracking Distance Education in the United States reveals an interesting paradox. Online education is both highly concentrated in the U.S., and also highly dispersed. In other words, a small number of institutions provide online learning for a 
large proportion of all distance learners - but a large number of schools are involved in some way in teaching online courses. In fact, of the 4,717 degree granting institutions in the U.S., fully 71 percent reported that they participated in online education. ${ }^{\text {ii }}$

This study aims to build a model for Online Program for English learners of software developers using logistic regression model.

\section{METHOD}

\subsection{Data}

The data is available at: https://nces.ed.gov/pubsearch/pubsinfo.asp?pubid=2016150

The 2015-16 survey Programs and Services for High School English Learners provides the first nationally representative data on this topic. This report is based on that survey and presents data on programs and services for high school English learners (ELs), including instructional approaches, newcomer programs, online or computer-based programs, and programs or services (e.g., tutoring) designed specifically for high school ELs. The report provides findings on the use of native language(s) for content instruction, instructional support, materials, and services. Data are presented about the information that districts provide about educational programs or services to ELs ages 18 to 21 seeking to newly enroll in the district, as well as the factors districts consider when providing information about these programs and services to ELs in this group.

\subsection{Statistical Analysis}

A public database was used in this study. All the participants who were eligible were randomly assigned into 2 groups: training sample and testing sample.Logistic regression was built using training sample. We used these two models to predict the career satisfaction of software developers in the testing sample. Sensitivity, specificity, receiver operating characteristic (ROC) were calculated.

\section{RESUltS}

A total of 918 schools offered online program for the English learners, representing about $79.1 \%$ of the total of 1161 schools.

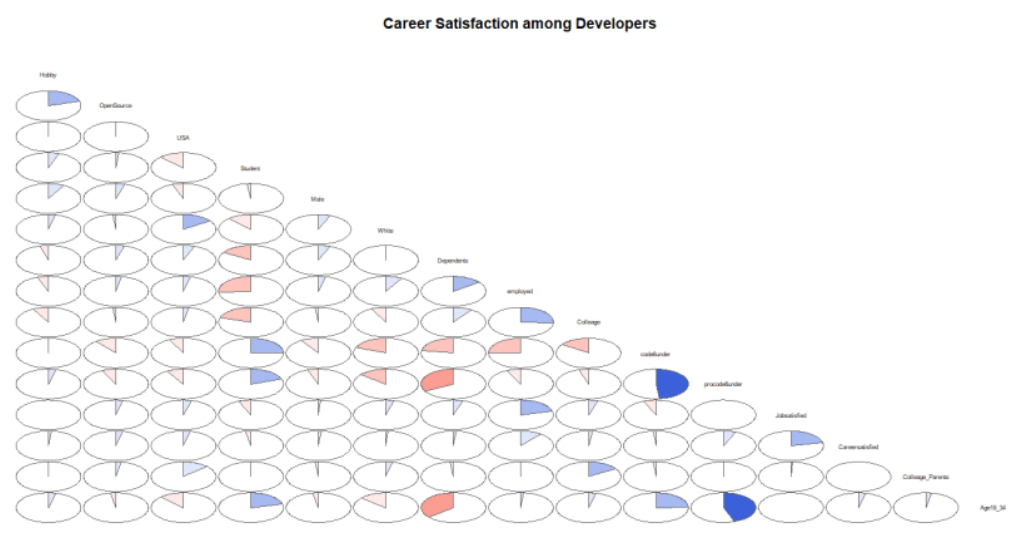

Figure1. matrix of correlations between variables

According to the logistic regression, the significant predictors of Online Program for English learners were regions, availabilities of bilingual instruction, English as a Second Language (ESL) instruction, English as a Second Language (ESL) push-in or pull-out instruction, instructional support by a paraprofessional who speaks the student's native language.

Table2. Logistic Regression for Online Program for English learners

\begin{tabular}{|l|r|r|r|r|l|}
\hline & Estimate & \multicolumn{1}{|l|}{ Std. Error } & \multicolumn{1}{|l|}{ z value } & $\operatorname{Pr}(>|\mathrm{z}|)$ & \\
\hline (Intercept) & 7.856 & 4.429 & 1.774 & 0.076 &. \\
\hline Q3A & -0.741 & 0.362 & -2.050 & 0.040 & $*$ \\
\hline Q3B & 0.185 & 0.465 & 0.398 & 0.691 & \\
\hline Q3C & -0.599 & 0.190 & -3.153 & 0.002 & $* *$ \\
\hline Q3D & -0.404 & 0.159 & -2.534 & 0.011 & $*$ \\
\hline Q3E & -0.195 & 0.174 & -1.121 & 0.262 & \\
\hline Q3F & -0.426 & 0.191 & -2.225 & 0.026 & $*$ \\
\hline Q3G & -0.222 & 0.172 & -1.295 & 0.195 & \\
\hline
\end{tabular}




\begin{tabular}{|c|c|c|c|c|c|}
\hline Q3H & -0.168 & 0.245 & -0.685 & 0.493 & \\
\hline Q4 & -2.326 & 3.654 & -0.637 & 0.524 & \\
\hline Q5 & -0.235 & 0.388 & -0.605 & 0.545 & \\
\hline enrollsize2k_5K & 0.025 & 0.193 & 0.129 & 0.897 & \\
\hline enrollsize 5K & 0.348 & 0.291 & 1.197 & 0.231 & \\
\hline City & 0.009 & 0.295 & 0.030 & 0.976 & \\
\hline Suburban & -0.057 & 0.222 & -0.258 & 0.796 & \\
\hline Town & -0.118 & 0.221 & -0.534 & 0.594 & \\
\hline Southeast & 1.124 & 0.270 & 4.166 & 0.000 & $* * *$ \\
\hline Central & 0.017 & 0.223 & 0.078 & 0.938 & \\
\hline West & 0.135 & 0.233 & 0.582 & 0.561 & \\
\hline
\end{tabular}

Schools in Southeast were $208 \%$ more likely to provide online program for English learners than schools in Northeast. Central and West regions had a slightly higher likelihood to offer online program than Northeast, however, the differences were not significant.

Schools which did not offer bilingual instruction were 52\% less likely to offer online English education. Schools which did not offer English as a Second Language (ESL) instruction were 45\% less likely to offer online education. Schools which did not offer English as a Second Language (ESL) push-in or pull-out instruction were 33\% less likely to have online program for English learners. Schools which did not provide instructional support by a paraprofessional who speaks the student's native language were $35 \%$ less likely to have online program.

\begin{tabular}{|l|l|l|l|}
\hline & OR & Risk Increase & \\
\hline Q3A & 0.477 & $-52 \%$ & $*$ \\
\hline Q3B & 1.204 & $20 \%$ & $*$ \\
\hline Q3C & 0.549 & $-45 \%$ & $*$ \\
\hline Q3D & 0.668 & $-33 \%$ & \\
\hline Q3E & 0.823 & $-18 \%$ & $*$ \\
\hline Q3F & 0.653 & $-35 \%$ & \\
\hline Q3G & 0.801 & $-20 \%$ & \\
\hline Q3H & 0.846 & $-15 \%$ & \\
\hline Q4 & 0.098 & $-90 \%$ & \\
\hline Q5 & 0.791 & $-21 \%$ & \\
\hline enrollsize2k_5K & 1.025 & $3 \%$ & \\
\hline enrollsize5K & 1.417 & $42 \%$ & \\
\hline City & 1.009 & $1 \%$ & \\
\hline Suburban & 0.944 & $-6 \%$ & \\
\hline Town & 0.889 & $-11 \%$ & \\
\hline Southeast & 3.077 & $208 \%$ & \\
\hline Central & 1.017 & $2 \%$ & \\
\hline West & 1.145 & $14 \%$ & \\
\hline
\end{tabular}

The distribution of the predicted probability to have a online program for the English learners among schools which did not have a online program (0) and which had a online program (1).

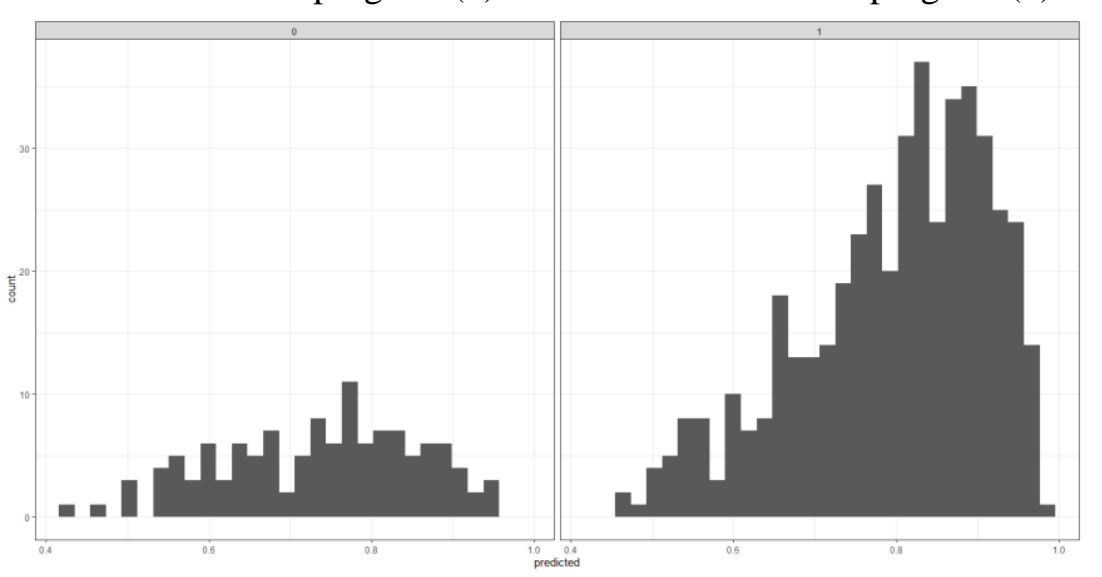

The area under curve was 0.6479 . The optional cutoff time is 0.4262 . The mis-classification error was 0.2083 . the sensitivity rate is about $100 \%$ and the specificity is $0.8 \%$. 


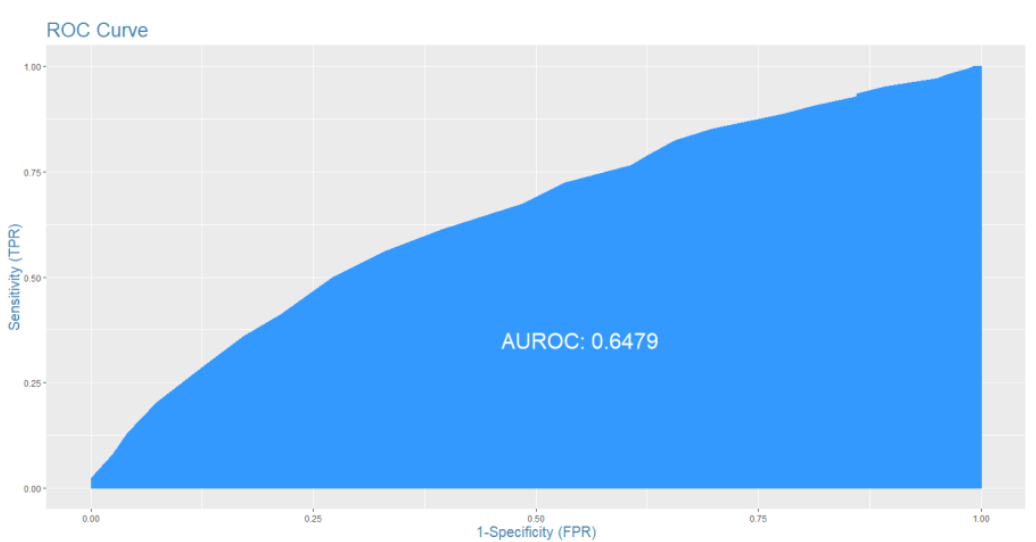

\section{DisCUSSIONS}

Schools in Southeast were 208\% more likely to provide online program for English learners than schools in Northeast. Central and West regions had a slightly higher likelihood to offer online program than Northeast, however, the differences were not significant.

Schools which did not offer bilingual instruction were 52\% less likely to offer online English education. Schools which did not offer English as a Second Language (ESL) instruction were 45\% less likely to offer online education. Schools which did not offer English as a Second Language (ESL) push-in or pull-out instruction were 33\% less likely to have online program for English learners. Schools which did not provide instructional support by a paraprofessional who speaks the student's native language were $35 \%$ less likely to have online program.

This study identified the potential predictors for online education for English learners, for example: regions, availability of other support for English as a Second Language.

\section{REFERENCES}

[1] Refer to https://vhslearning.org/virtual-education-future-k-12-students

[2] Refer to https://www.insidehighered.com/blogs/technology-and-learning/looking-future-online-educationthrough-strategic-institutional-lens

[3] Peng, C. J., Lee, K. L., Ingersoll, G. M. An Introduction to Logistic Regression Analysis and Reporting. The Journal of Educational Research, 96(1), 3-14.

[4] Tabachnick, B., and Fidell, L. Using Multivariate Statistics (4th Ed.). Needham Heights, MA: Allyn \& Bacon, 2001.

[5] StatSoft, Electronic Statistics Textbook, http://www.statsoft.com/textbook/stathome.html.

[6] Stokes, M., Davis, C. S. Categorical Data Analysis Using the SAS System, SAS Institute Inc., 1995.

\section{AUTHOR'S BIOGRAPHY}

Ms. Qing Chen, graduated from college majoring in English in 1990. She is a senior English teacher at the Experimental High School affiliated to Beijing Normal University. She has over 30 years of experience of teaching English to middle school and high school students. In addition to classroom teaching, she did extensive exploration in online English teaching, and got exciting research results.

Citation: Ms. Qing Chen."Online Education Program for English Learners in High Schools" International Journal of Humanities Social Sciences and Education (IJHSSE), vol 8,no.1, 2021, pp.55-58. doi:https://doi.org/ 10.20431/2349-0381.0801007.

Copyright: (C) 2021 Authors. This is an open-access article distributed under the terms of the Creative Commons Attribution License, which permits unrestricted use, distribution, and reproduction in any medium, provided the original author and source are credited.

\footnotetext{
ihttps://vhslearning.org/virtual-education-future-k-12-students

${ }^{i i}$ https://www.insidehighered.com/blogs/technology-and-learning/looking-future-online-education-throughstrategic-institutional-lens
} 